Ivan Setiawan, Septia Winduwati: Aktivitas Komunikasi Interpersonal Barista Dalam Mempertahankan Citra Starbucks Chinatown

\title{
Aktivitas Komunikasi Interpersonal Barista dalam Mempertahankan Citra Starbucks Chinatown
}

\author{
Ivan Setiawan, Septia Winduwati \\ Ivan.915160187@stu.untar.ac.id,septiaw@fikom.untar.ac.id
}

Fakultas Ilmu Komunikasi Universitas Tarumanagara

\begin{abstract}
This thesis aims to find out how baristas communicate to consumers in order to maintain the company's image. The theory used is the theory of interpersonal communication, interpersonal communication in business. This research uses qualitative approach and uses the case study methods. The subject of this research was Barista who was placed in Starbucks Chinatown. Researchers get information about what is needed by conducting online interviews with informants. The results showed that Barista applied all aspects of attitude related to the purpose of interpersonal communication in business, namely conveying information, sharing experiences, feeling sympathy, collaborating, overcoming complaints from customers, and also motivating or supporting consumers. Conveying information done by Barista often occurs between Barista and consumers at the POS (cash register). Sharing experiences occurs two-way communication between baristas and consumers. Barista also keeps in a relationship and cooperates outside working hours. Barista is professional in dealing with resentment or disappointment of consumers.
\end{abstract}

Keywords: interpersonal communication, corporate image, barista, starbucks.

\begin{abstract}
Abstrak
Penelitian ini bertujuan untuk mengetahui bagaimana cara barista berkomunikasi kepada konsumen demi mempertahankan citra perusahaan. Teori yang dipakai adalah teori komunikasi antarpribadi, komunikasi interpersonal dalam bisnis. Dalam penelitian ini, peneliti melakukan penelitian dengan menggunakan pendekatan kualitatif dan menggunakan metode studi kasus. Subyek penelitian ini yaitu barista di Starbucks Chinatown. Peneliti mendapatkan informasi tentang apa yang dibutuhkan dengan melakukan wawancara secara online dengan para informan. Hasil penelitian menunjukkan bahwa barista menerapkan semua aspek sikap yang berhubungan dengan tujuan komunikasi interpersonal dalam bisnis, yaitu menyampaikan informasi, berbagi pengalaman, rasa simpati, melakukan kerja sama, mengatasi keluhan dari pelanggan, dan juga memotivasi atau mendukung konsumen. Penyampaian informasi sering terjadi antara barista dan konsumen di POS (mesin kasir). Terjadi komunikasi dua arah antara barista dan konsumen. Barista juga tetap menjalin hubungan dan melakukan kerjasama di luar jam kerja. Barista juga professional ketika menghadapi kekesalan atau kekecewaan konsumen.
\end{abstract}

Kata Kunci: komunikasi interpersonal, citra perusahaan, barista, starbucks. 


\section{Pendahuluan}

Komunikasi merupakan bertukar pesan-pesan dalam bentuk pemikiran dari individu satu dan individu lainnya, yang tidak hanya menggunakan kata-kata atau kalimat, tetapi juga intonasi, ekspresi wajah, titik putus lokal dan sebagainya (Ngalimun, 2016:28).

Manusia dan masyarakat melakukan komunikasi dalam mengungkapkan diri sendiri, untuk membentuk sosial dalam kehidupan bermasyarakat, serta untuk memberikan pengaruh kepada masyarakat lainnya untuk mempunyai pola pikir dan perilaku seperti apa yang diinginkan sehingga, dengan menjalin komunikasi yang baik, individu mempersuasi individu lain untuk berperilaku sesuai apa yang diinginkan, tetapi terkadang individu merasakan komunikasi yang kurang efektif dikarenakan kesalahan dalam menangkap pesan yang diterimanya. Komunikasi menjadi kunci penting dalam berbagai aspek kehidupan, misalnya dalam hal pemasaran (Mulyana, 2012:4)

Menurut Syam (2012) komunikasi terbagi menjadi sembilan bentuk,yaitu: komunikasi intrapersonal, komunikasi interpersonal, komunikasi kelompok, komunikasi publik, komunikasi organisasi, komunikasi massa, komunikasi antarbudaya, komunikasi internasional, komunikasi global. Komunikasi yang sering dijumpai dalam kehidupan bermasyarakat adalah komunikasi interpersonal. Komunikasi interpersonal sering terjadi didalam kehidupan manusia untuk menjalin pertemanan, maupun ruang lingkup organisasi atau perusahaan.

Menurut Pearson, dkk (2011), komunikasi interpersonal adalah suatu proses yang digunakan dalam pesan-pesan untuk mendapatkan kesamaan arti setidaknya antar dua orang di dalam sebuah kondisi yang memungkinkan adanya kesempatan yang sama bagi pembicara dan pendengar.

Bagi sebagian perusahaan, komunikasi antarpribadi atau interpersonal sangat dibutuhkan demi meningkatkan maupun mempertahankan citra baik dan hubungan yang baik di masyarakat, terutama coffee shop. Coffee shop merupakan salah satu bisnis yang banyak diminati oleh masyarakat Indonesia (www.maxmanroe.com diakses pada 1 Juni 2020).

Starbucks adalah salah satu perusahaan raksasa yang bergerak dibidang coffee shop dan sudah memiliki lebih dari 30.000 cabang di seluruh dunia. Starbucks pertama kali membuka cabang di Indonesia, tepatnya di Plaza Indonesia Jakarta pada tanggal 17 May 2002. Dan sekarang, starbucks sudah memiliki 326 cabang di 22 kota di Indonesia. (www.starbucks.co.id dan www.starbucks.com diakses pada 24 Februari 2020)

Dalam berinteraksi dengan pelanggan pada hasil obervasi awal penulis, barista Starbucks menjunjung tinggi etika dan kenyaman pelanggan. Barista Starbucks selalu tersenyum dan melakukan eye contact, menyapa terlebih dahulu, contohnya "Selamat datang di Starbucks" atau mengucapkan salam terlebih dahulu, say thank you first kepada pelanggan.

Hal tersebut adalah salah satu komunikasi interpersonal yang terjadi di antara barista dan customers. Hal ini dilakukan supaya terjadinya kepuasan customers dan kenyamanan terhadap pelayanan barista Starbucks.

Dalam penelitian ini, peneliti berusaha meneliti aktivitas komunikasi interpersonal yang dilakukan barista Starbucks Chinatown. Alasannya adalah karena peneliti sering mengunjungi Starbucks Chinatown. Maka peneliti memilih judul 
Ivan Setiawan, Septia Winduwati: Aktivitas Komunikasi Interpersonal Barista Dalam Mempertahankan Citra Starbucks Chinatown

penelitian sebagai berikut: Aktivitas Komunikasi Interpersonal Barista dalam Mempertahankan Citra Starbucks Chinatown.

\section{Metode Penelitian}

Metode penelitian yang diaplikasikan dalam penelitian ini adalah studi kasus. Herdiansyah (2010:76) menjabarkan bahwa studi kasus adalah suatu model yang menekankan eksplorasi dari suatu sistem yang terbatas pada suatu (beberapa) kasus secara mendetail, disertai dengan penggalian secara mendalam terhadap data yang melibatkan berbagai sumber informasi yang melimpah akan konteks. Marshall dan Rossman menyatakan bahwa pada penelitian kualitatif, pengumpulan data harus dilakukan pada kondisi yang natural dan tidak dibuat-buat, dan lebih banyak pada observasi berperan, wawancara mendalam dan dokumentasi (Sugiyono, $2016: 63$ ).

Terkait teknik pengolahan dan analisis data, Bogdan mengungkapkan analisis data adalah proses menarik kesimpulan dari sumber-sumber, seperti catatan dari lapangan, hasil wawancara, sehingga dapat dipahami dan temuan tersebut berguna dalam memberikan informasi kepada masyarakat. Analisis data dilakukan dengan memisahkan data, menjabarkan ke dalam unit-unit, menyusun ke dalam pola, memilih mana yang penting dan membuat kesimpulan yang dapat diceritakan kepada orang lain (Sugiyono, $2016: 88$ ).

Arikunto (2016) mengemukakan subyek penelitian merupakan suatu benda (tempat) untuk penelitian dalam permasalahan berada. Adapun kriteria yang akan dijadikan informan dalam penelitian ini adalah barista Starbucks yang sudah bekerja sebagai barista lebih dari 6 bulan guna mendapatkan informasi yang lebih detail dan konsumen Starbucks Chinatown.

Definisi dari objek penelitian adalah suatu isu (tema) yang sedang diteliti (Idrus, 2009 : 91). Obyek dalam penelitian ini adalah komunikasi antarpribadi antara barista dan pelanggan Starbucks Chinatown.

\section{Hasil Temuan dan Diskusi}

PT. Sari Coffee Indonesia merupakan perusahaan yang pertama kali membawa Starbucks masuk ke Indonesia Starbucks Coffee membuka gerai pertamanya di Indonesia pada tanggal 17 Mei 2002. Gerai tersebut berlokasi di Plaza Indonesia, Jakarta Pusat. Sejak saat itu, pasar Starbucks Coffee di Indonesia berkembang dengan pesat, dan Starbucks Coffee pun membuka gerai-gerai lainnya di kota-kota besar di Indonesia, seperti di Bandung, Bali, Pekanbaru, Semarang, Yogyakarta, Makassar, Medan, dan Surabaya . (http://www.starbucks.co.id/aboutus/)

Peneliti melakukan penelitian di Starbucks Coffee Indonesia Chinatown. Fokus penelitian ini adalah aktivitas komunikasi interpersonal barista Starbucks dengan pelanggan. Pada penelitian ini, peneliti menggunakan teori Efektivitas Komunikasi (pendekatan humanistik). Menurut Ardianto (2014) terdapat lima aspek sikap positif yang dipertimbangkan ketika seseorang merencanakan komunikasi antarpribadi: keterbukaan, empati, sikap mendukung, sikap positif, dan kesetaraan.

Selain itu, peneliti juga menggunakan konsep tujuan komunikasi interpersonal dalam bisnis. Menurut Djoko (2011) tujuan komunikasi interpersonal yaitu menyampaikan informasi, berbagi pengalaman, menumbuhkan simpati, 
melakukan kerja sama, menceritakan kekecewaan dan kekesalan, menumbuhkan motivasi.

Berdasarkan wawancara yang telah dilakukan olehp eneliti kepada para informan didapat hasil bahwa lima aspek sikap positif yang terdapat pada teori efektivitas komunikasi, adalah sudah dilakukan oleh antar sesama barista maupun antara barista dengan konsumen.

Hal ini dilakukan mulai dari menerima kritik dan saran dari konsumen agar sesuai dengan selera konsumen (keterbukaan), berperilaku ramah dan baik serta memberikan pelayanan terbaik (empati), memberikan kalimat-kalimat spontan dengan senang hati yang membahagiakan para customer (sikap mendukung), memberi sapaan ramah (sikap positif), dan tidak membeda-bedakan perlakuan ke seluruh konsumen dari segi apapun (kesetaraan).

Sementara konsep tujuan komunikasi interpersonal direalisasikan mulai dari, penyampaian menu Starbucks dan pembicaraan mengenai produk (menyampaikan informasi), perbincangan antara konsumen dan barista (berbagi pengalaman), inisiatif untuk membantu konsumen walau jam bekerja sudah berakhir (menumbuhkan simpati), hubungan akrab barista-barista dan barista-konsumen (melakukan kerja sama), mendengar dan meminta maaf jika terjadi komplain dari pelanggan (menceritakan kekecewaan atau kekesalan), memberikan kalimat-kalimat postitif/semangat di gelas (menumbuhkan motivasi).

Berdasarkan jawaban yang sudah diberikan oleh ketiga informan dalam penelitian ini, peneliti menyimpulkan bahwa penyampaian informasi yang dilakukan barista kepada konsumen tentang produk yang dijual sudah sangat efektif. Barista sangat mengerti tentang produk yang dijualnya dan konsumen pun merasa puas dengan penyampaian informasi yang diberikan oleh barista.

Komunikasi yang interaktif antara barista dan konsumen. Komunikasi ini menggambarkan alur yang setiap pelaku komunikasinya dapat saling mengirimkan pesan kemudian diterjemahkan yang selanjutnya dapat diteruskan dengan feedback kepada pengirim pesan dan hal ini berlangsung secara terus menerus dan dapat dibuktikan melalui kejadian yang sudah terjadi dan dialami oleh barista maupun customer dalam penelitian ini.

Hubungan yang terjalin antara barista dan konsumen tidak hanya disaat jam kerja, tetapi juga diluar jam kerja. Barista dan konsumen sesekali melakukan kegiatan bersama diluar jam kerja. Ini menandakan hubungan yang terjalin antara barista dan konsumen sudah menuju ke tahap pertemanan.

Barista Starbucks Chinatown juga sering menerima keluhan. Barista memiliki cara atau langkah-langkah profesional dalam menghadapi keluhan tersebut. Cara atau langkah-langkah tersebut adalah L.A.T.T.E ((Listen to the customer, Acknowledge them (apologize), Thank them for the feedback, Take Action, and Explain what you've done to handle the issue and improve).

Customer juga merasa bahwa barista mendukung dengan cara memberikan kalimat-kalimat secara spontan yang memotivasi dan juga dengan senang hati menuruti kemauan customer untuk menuliskan kalimat-kalimat yang diinginkan. Barista selalu mendukung customer dengan memberikan kalimat-kalimat spontan dan dengan senang hati yang membahagiakan para customer.

\section{Simpulan}

Berdasarkan penelitian yang sudah dilakukan melalui wawancara dengan para 
Ivan Setiawan, Septia Winduwati: Aktivitas Komunikasi Interpersonal Barista Dalam Mempertahankan Citra Starbucks Chinatown

informan, maka peneliti menarik kesimpulan bahwa komunikasi interpersonal barista dan konsumen yang dilakukan melalui pendekatan humanistik dan juga tujuan komunikasi interpersonal dalam bisnis. Tujuan komunikasi interpersonal dalam bisnis meliputi menyampaikan informasi, berbagi pengalaman, menumbuhkan simpati, melakukan kerja sama, menumbuhkan motivasi. Menyampaikan informasi dilakukan barista sering terjadi antara barista dan konsumen di POS (mesin kasir). Terjadi komunikasi dua arah antara barista dan konsumen saat berbagi pengalaman. Sesekali muncul rasa simpati barista di Starbucks Chinatown. Barista juga tetap menjalin hubungan dan melakukan kerjasama di luar jam kerja. Barista menghadapi kekesalan dan kekecewaan konsumen secara profesional cara listen to the customer, acknowledge them (apologize), thank them for the feedback, take action, and explain what you've done to handle the issue and improve).

\section{Ucapan Terima Kasih}

Pertama-tama penulis mengucapkan terima kasih kepada Tuhan YME atas terselesaikannya jurnal ini dengan baik. Selanjutnya, peneliti berterima kasih sebesar-besarnya kepada keluarga dan semua informan yang bersedia untuk diwawancarai. Peneliti berterima kasih kepada seluruh pihak yang memberi dukungan juga bantuan hingga akhirnya penelitian ini dapat terselesaikan dengan baik.

\section{Daftar Pustaka}

Ardianto, Elvinaro. (2014). Hand Book of Public Relations:Pengantar Komprehensif. Bandung : Simbiosa Rekatama Media.

DeVito, Joseph A. (2013). The Interpersonal Communication Book (ed. 13). United States: Pearson Education

Herdiansyah, Haris. (2010). Metodologi Penelitian Kualitatis Untuk Ilmu-Ilmu Sosial. Jakarta Selatan: Salemba Humanika.

Mulyana, Deddy. 2012. Ilmu Komunikasi Suatu Pengantar. Bandung: PT Remaja Rosdakarya

Moleong, Lexy J. (2018). Metodologi Penelitian Kualitatif. Bandung : PT Remaja Rosdakarya

Ngalimun. 2016. Komunikasi Interpersonal. Yogyakarta : Pustaka Belajar

Pearson, Judy C. 2011. Human Communication. New York : Aptara

10+ Bisnis yang Laku Setiap Hari di Pasaran dan Bisa Dikerjakan Siapa Saja. Maret 10, 2020. https://www.maxmanroe.com/bisnis-yang-laku-setiaphari.html

Starbucks Coffe. About Us. Februari 26. 2020. http://www.starbucks.co.id/about-us Sugiyono. 2010. Memahami Penelitian Kualitatif. Bandung : Alfabeta

Ambar. (2017). Maret 8, 2020. Komunikasi Interpersonal - Pengertian, Elemen, Sifat dan Prinsip.

http://pakarkomunikasi.com/komunikasi-interpersonal 